\title{
VALIDITAS DAN PRAKTIKALITAS PENUNTUN PRAKTIKUM KIMIA BERBASIS GREEN CHEMISTRY UNTUK SEMESTER GENAP KELAS X IPA SMA
}

\author{
Susilawati Amdayani \\ Surel: susilawatiamdayani@unimed.ac.id
}

\begin{abstract}
This study aims to develop a practical and valid green chemistry based practical guide for grade X SMA. This type of research is the development of research with $4 D$ models consisting, $4 D$ Models consist of four stages : define, design, develop and disseminate. Based on the results of the descriptive analysis of the data obtained, it can be stated that: 1) The green chemistry -based practicum guide developed is very valid, indicated by the kappa value obtained from the four validators 0,88 with a very high category; 2) The geen chemistry-based practicum guide developed is very practical, indicates bt the kappa value obtained from the practicality test of teachers and students is 0,89. And 0,81 with is very high categories From the results of validity and practicality test that have been done, it can be concluded that moduls have been developed are suitable for use as a learning resources.
\end{abstract}

Keywords : Validity, Practicality, Green Chemistry

\begin{abstract}
ABSTRAK
Penelitian ini bertujuan untuk mengembangkan panduan praktikum berbasis green chemistry yang praktis dan valid untuk siswa kelas $\mathrm{X}$ SMA. Jenis penelitian ini adalah penelitian pengembangan dengan menggunakan model 4D yang terdiri dari, Model 4D terdiri dari empat tahap yaitu define, design, develop dan disebarluaskan. Berdasarkan hasil analisis deskriptif terhadap data yang diperoleh, dapat dinyatakan bahwa: 1) Panduan praktikum berbasis green chemistry yang dikembangkan sangat valid, ditunjukkan dengan nilai kappa yang diperoleh dari keempat validator sebesar 0,88 dengan nilai sangat tinggi. kategori; 2) Panduan praktikum berbasis kimia geen yang dikembangkan sangat praktis, menunjukkan nilai kappa yang diperoleh dari uji praktikalitas guru dan siswa adalah 0,89. Dan 0,81 dengan kategori sangat tinggi Dari hasil uji validitas dan uji kepraktisan yang telah dilakukan dapat disimpulkan bahwa modul yang telah dikembangkan layak untuk digunakan sebagai sumber belajar.
\end{abstract}

Kata Kunci : Validitas, Praktikalitas, Kimia Hijau

\section{PENDAHULUAN}

Ilmu kimia mempelajari materi dan perubahannya, bahan kajian ilmu kimia antaranya lain adalah sifat-sifat zat termasuk struktur zat, perubahan zat (reaksi kimia), energi yang terlibat, hukum, prinsip, dan teori (Chang, 2003:3). Ilmu kimia merupakan experimental science, tidak dapat dipelajari hanya melalui membaca, menulis, atau mendengarkan saja.

Ilmu kimia dipelajari bukan hanya untuk menguasai atau 
memahami kumpulan pengetahuan berupa fakta, konsep, prinsip saja tetapi juga merupakan suatu proses penemuan dan penguasaan prosedur atau metode ilmiah. Salah satu kegiatan dalam pembelajaran yang menggunakan metode ilmiah adalah kegiatan praktikum.

Berdasarkan hasil wawancara pada beberapa orang guru kimia SMA di Kabupaten Solok, kegiatan praktikum masih jarang dilaksanakan di sekolah. Sementara untuk beberapa indikator pada materi kimia dibutuhkan adanya pelaksanaan praktikum oleh siswa, seperti pada pokok bahasan larutan elektrolit dan non elektrolit, reaksi reduksi dan oksidasi serta hukum dasar kimia.

Pada dasarnya praktikum tetap dapat dilaksanakan dengan menggunakan alat-alat sederhana, bahan- bahan alami serta bahanbahan sederhana yang mudah didapatkan dalam kehidupan seharihari. Hal ini sesuai dengan konsep green chemistry yang dikemukakan EPA (Environmental Protection Agency) bekerja sama dengan ACS (American Chemical Society). Green chemistry merupakan suatu falsafah atau konsep yang mendorong mengurangi penggunaan dan menghasilkan zat-zat berbahaya serta memaksimalkan efisiensi dari penggunaan zat-zat (substansi) kimia (Kapuderwan, 2011: 199).

Melaksanakan kegiatan praktikum memerlukan penuntun praktikum yang berguna untuk siswa melaksanakan kegiatan praktikum secara sistematis dan aman.
Berdasarkan hasil wawancara dengan guru mata pelajaran kimia di beberapa Sekolah Menengah Atas Kabupaten Solok, diketahui bahwa guru menggunakan penuntun praktikum yang disusun oleh guru mata pelajaran sendiri dan penuntun praktikum yang terdapat pada buku siswa terbitan penerbit tertentu. Pada sekolah yang laboratoriumnya tidak lengkap seperti sekolah yang terdapat di daerah pedesaan sulit untuk menggunakan penuntun praktikum yang telah ada dalam melaksanakan kegiatan praktikum. Hal ini disebabkan karena terbatasnya alat dan bahan yang digunakan untuk melaksanakan praktikum. Oleh karena itu, peneliti memberikan solusi supaya kegiatan praktikum tetap dilaksanakan dengan mengembangkan penuntun praktikum berbasis green chemistry.

Menurut Peratiwi (2014:68), buku pedoman praktikum berbasis green chemistry atau ramah lingkungan dalam hal ini bertujuan mencegah dan mengurangi dampak negatif yang ditimbulkan selama pelaksanaan praktikum, baik bagi lingkungan dan dampak bagi kesehatan manusia.

Cara mencegah supaya dampak negatif tersebut tidak terjadi dilakukan dengan mengganti bahanbahan kimia berbahaya dengan menggunakan bahan-bahan kimia ramah lingkungan.

Adapun tujuan penelitian ini adalah 1) menentukan validitas penuntun praktikum kimia berbasis green chemistry 2) menentukan 
Susilawati Amdayani : Validitas dan Praktikalitas ...

praktikalitas penuntun praktikum kimia berbasis green chemistry.

\section{METODE PENELITIAN}

Jenis penelitian yang digunakan adalah penelitian pengembangan dengan model 4D (four $D$ models). Tahapan utama Model 4-D, yaitu: (1) define (pendefenisisan), (2) design (perancangan), (3) develop (pengembangan) dan (4) disseminate (penyebaran) (Thiagarajan,1974:6).

Pelaksanaan penelitian dimulai dari tahap pendefenisian. Pada tahap ini langkah-langkah yang dilakukan adalah analisis ujung depan, analisis tugas, analisis konsep, analisis siswa dan spesifikasi tujuan pembelajaran.

Pada tahap perancangan dilakukan pemilihan media ,dilanjutkan dengan pemilihan format dimana penuntun praktikum kimia yang akan dikembangkan, dirancang sesuai dengan format penulisan penuntun praktikum yang terdapat pada Keputusan Mendiknas No.36 Tahun 2001. Kemudian dibuatlah rancangan awal penuntun praktikum kimia ini berisikan judul praktikum, tujuan praktikum, penyajian informasi, arahan pertanyaan ilmiah untuk merumuskan hipotesis sementara, alat dan bahan yang digunakan, prosedur kerja, tabel pengamatan, panduan berupa pertanyaan untuk menerima atau menolak hipotesis serta membuat kesimpulan.

Adapun tahap pengembangan dilakukan berdasarkan penilaian dari para ahli melalui uji validitas.
Sebelumnya instrumen di validasi oleh 2 orang dosen kimia. Validasi yang dilakukan yaitu validasi isi dan validasi konstruk. Selanjutnya dilakukan revisi yang bertujuan untuk memperbaiki bagian penuntun praktikum yang dianggap masih kurang tepat oleh validator sebelum produk diuji coba. Setelah produk dinyatakan valid, maka dilakukan uji praktikalitas pada 20 orang guru kimia dan selanjutnya penuntun di ujicobakan pada masing-masing siswa sebanyak 20 orang siswa kelas X IPA SMA N I Pantai Cermin dan siswa kelas $X$ IPA SMAN I Lembah Gumanti.

\section{HASIL PENELITIAN DAN PEMBAHASAN}

\section{Data Hasil Tahap Pendefenisisan}

Berdasarkan hasil wawancara dengan 5 orang guru kimia SMA di Kabupaten Solok, diketahui bahwa praktikum perlu dilaksanakan dalam pembelajaran kimia. Namun kenyataannya, tidak semua sekolah dapat melaksanakan praktikum. Hal ini disebabkan karena terbatasnya alat dan bahan yang digunakan untuk melaksanakan praktikum.

Secara umum guru juga membutuhkan bahan ajar berupa penuntun praktikum dalam melaksanakan kegiatan praktikum. Penggunaan penuntun praktikum bertujuan agar kegiatan praktikum lebih terarah dan sistematis. Selain itu, penggunaan penuntun praktikum diharapkan dapat mempermudah siswa saat bekerja di laboratorium ataupun di luar laboratorium. 
Berdasarkan wawancara dengan siswa, hasilnya diketahui bahwa siswa-siswa membutuhkan praktikum dalam pembelajaran kimia. Kegiatan praktikum dapat mengembangkan keterampilan psikomotorik, menarik, menyenangkan, dan juga membantu siswa dalam memahami materi kimia. Siswa juga membutuhkan penuntun praktikum dalam melaksanakan kegiatan praktikum. Penuntun praktikum berguna untuk siswa dapat melaksanakan kegiatan praktikum.

$$
\text { Berdasarkan analisis }
$$

kompetensi dasar pada kurikulum 2013 mata pelajaran kimia kelas X IPA SMA, indikator yang perlu diringi dengan metoda praktikum adalah; (1) melakukan percobaan untuk mengidentifikasi sifat-sifat larutan elektrolit (air aki 0,1 $\mathrm{M}$, larutan soda api $0,1 \mathrm{M}$, larutan garam dapur $10 \%$, larutan sabun $10 \%$, larutan kapur $10 \%$, larutan asam cuka $0,1 \mathrm{M}$ ) dan non elektrolit (air sumur, larutan gula $10 \%$, alkohol $70 \%$ ), (2) melakukan pengelompokkan larutan yang digunakan dalam percobaan berdasarkan sifat hantaran listriknya ke dalam larutan elektrolit dan non elektrolit (3) menjelaskan penyebab kemampuan larutan elektrolit menghantarkan arus listrik, (4) memahami pengertian reduksi dan oksidasi setelah mengamati persamaan reaski yang terdapat pada kegiatan praktikum korosi, Rancangan awal penuntun praktikum kimia berbasis green chemistry untuk semester genap kelas $X$ IPA SMA terdiri atas enam merancang percobaan konsep redoks dalam kehidupan sehari-hari yaitu browning pada buah apel dan korosi,(6) melakukan percobaan konsep redoks dalam kehidupan sehari-hari yaitu browning pada buah apel dan korosi, (7) membuktikan hukum Lavoisier melalui percobaan dengan mereaksikan soda kue dengan asam cuka, (8) membuktikan berlakunya hukum perbandingan tetap (Proust) melalui percobaan mereaksikan serbuk besi dan belerang dan (9) membuktikan berlakunya hukum perbandingan volum (Hukum Gay Lussac) melalui percobaan balon yang diikatkan pada ujung botol dan dimasukkan ke dalam air panas dan air dingin. Berdasarkan hasil pada tahap pendefenisian maka dikembangkan penuntun praktikum kimia berbasis green chemistry untuk semester genap kelas X IPA SMA meliputi materi larutan elektrolit dan non-elektrolit, konsep reaksi reduksi oksidasi dan hukum dasar kimia.

\section{Data Hasil Tahap Perancangan}

Setelah tahap pendefenisian selesai, maka dirancanglah penuntun praktikum. Media yang dipilih adalah penuntun praktikum kimia berbasis green chemistry dengan sistematika penulisan penuntun praktikum dirancang sesuai dengan format penulisan penuntun praktikum yang terdapat pada Keputusan Mendiknas No. 36 Tahun 2001.

kegiatan yaitu larutan elektrolit dan non elektrolit, browning pada buah apel, korosi, hukum kekekalan massa, hukum perbandingan tetap dan 
hukum perbandingan volume. Selain itu, komponen pada penuntun praktikum juga dilengkapi dengan cover, identitas pemilik, kata pengantar, tata tertib praktikum, alat-alat kimia dilaboratorium, bahan kimia di laboratorium, bahaya bahan kimia, prinsip green chemistry, aplikasi green chemistry, sebaiknya kamu tahu, penuntun praktikum kimia berbasis green chemistry dan kegiatan praktikum.

\section{Data Hasil Tahap Pengembangan}

Tahap pengembangan dilakukan dengan tujuan menghasilkan produk yang valid dan praktis sehingga produk yang dihasilkan layak digunakan pada proses pembelajaran khususnya kegiatan praktikum. Kegiatan yang dilakukan pada tahap pengembangan adalah kegiatan validasi produk dan uji praktikalitas produk. Penilaian pada tahap ini menggunakan instrumen validitas dan instrumen praktikalitas berupa angket. Tahap validasi produk dimulai dengan memvalidasi penuntun praktikum oleh pakar (dosen dan guru).

Kegiatan validasi ini dilakukan untuk menilai kelayakan penuntun praktikum ditinjau dari komponen isi, penyajian dan bahasa yang digunakan. Tahap uji praktikalitas produk bertujuan untuk mengetahui sejauh mana manfaat, kemudahan penggunaan dan efisiensi waktu penggunaan penuntun praktikum berbasis green chemistry oleh guru dan siswa.

Sebelumnya instrumen validasi dan angket praktikalitas juga di validasi terlebih dahulu oleh validator yaitu Dr. Hardeli, M.Si dan Dr. Mawardi, M.Si. Selanjutnya dilakukan uji validitas pada validator yang terdiri dari 2 orang dosen kimia dan 2 orang guru. Validator diminta untuk memberikan penilaian dan saran terhadap rancangan penuntun praktikum meliputi komponen isi, kelayakan konstruksi dan komponen bahasa.

Penuntun praktikum direvisi atas saran-saran yang diberikan oleh validator, revisi akan dihentikan sampai validator menyatakan kalau penuntun praktikum telah valid. Setelah penuntun dinyatakan valid, tahap pengembangan dilanjutkan dengan uji praktikalitas terhadap guru dan siswa. Guru diminta untuk memberikan penilaian mengenai keterpakaian penuntun praktikum di sekolah, sedangkan siswa diminta melakukan semua kegiatan pada penuntun praktikum lalu memberikan tanggapan atas kegiatan praktikum yang telah dilakukan.

\section{Pembahasan}

Penuntun praktikum yang dikembangkan dapat dikatakan valid untuk digunakan dalam proses pembelajaran apabila telah memenuhi validitas isi dan validitas konstruk (Van den Akker, 1999:10).

Data uji validitas dari lembaran validasi sedangkan uji praktikalitas dari angket respon guru dan siswa. data yang dikumpulkan selanjutnya dianalisis menggunakan momen kappa. Hasil uji validitas dan 
praktikalitas penuntun praktikum dilihat pada Tabel 1 berikut ini. kimia berbasis green chemistry dapat

Tabel 1. Hasil Uji Validitas dan Praktikalitas Penuntun Praktikum

\begin{tabular}{c|c|c}
\hline Data & $\begin{array}{c}\text { Momen } \\
\text { Kappa } \\
(\mathbf{k})\end{array}$ & Kategori \\
\hline Hasil uji validitas & 0,88 & $\begin{array}{c}\text { Sangat } \\
\text { valid }\end{array}$ \\
\hline $\begin{array}{c}\text { Hasil uji praktikalitas } \\
\text { terhadap guru }\end{array}$ & 0,89 & $\begin{array}{c}\text { Sangat } \\
\text { praktis }\end{array}$ \\
\hline $\begin{array}{c}\text { Hasil uji validitas } \\
\text { terhadap siswa sma n i } \\
\text { pantai cermin }\end{array}$ & 0,81 & $\begin{array}{c}\text { Sangat } \\
\text { praktis }\end{array}$ \\
\hline $\begin{array}{c}\text { Hasil uji validitas } \\
\text { terhadap siswa sma n i } \\
\text { lembah gumanti }\end{array}$ & 0,81 & $\begin{array}{c}\text { Sangat } \\
\text { praktis }\end{array}$ \\
\hline
\end{tabular}

Berdasarkan Tabel 1, penuntun praktikum berada pada kategori kevalidan sangat tinggi dengan perhitungan momen kappa sebesar 0,88 . Secara keseluruhan dapat dikatakan bahwa dari aspek isi, penuntun praktikum meliputi indikator, tujuan praktikum, penyajian materi, konsep, prosedur, uraian pertanyaan dikategorikan valid karena sesuai dengan kompetensi dasar dan materi kimia di semester genap kelas $X$ IPA SMA. Hal ini sesuai dengan pernyataan Van den Akker (1999:10) yang menyatakan bahwa validitas isi berhubungan dengan kesesuaian penuntun praktikum yang dikembangkan dengan prinsip pengetahuan.

Pengembangan penuntun praktikum memiliki karakteristik, yakni praktikum kimia di SMA dengan menggunakan bahan kimia ramah lingkungan sebagai bahan pengganti bahan berbahaya. Bahan kimia tersebut merupakan bahanbahan yang tidak memiliki efek negatif sehingga aman digunakan bagi kesehatan dan lingkungan, kelebihan lainnya dalam menggunakan bahan kimia ramah lingkungan adalah bahannya mudah diperoleh dalam kehidupan seharihari dengan harga yang mudah dijangkau atau relatif murah.

Contoh bahan yang digunakan dalam praktikum kimia ramah lingkungan adalah baking soda dan asam cuka. Baking soda atau soda kue memiliki rumus kimia $\mathrm{NaHCO}_{3}$. Senyawa ini berbentuk kristal serbuk yang berwarna putih. Baking soda digunakan sebagai bahan untuk mengembangkan roti. Asam cuka atau asam asetat dengan rumus kimia $\mathrm{CH}_{3} \mathrm{COOH}$ merupakan bahan yang sering digunakan dalam masakan dan memberikan rasa masam pada makanan dan sering digunakan sebagai pengawet makanan. Adapun 
kedua bahan ini digunakan sebagai penuntun praktikum kimia berbasis green chemistry dengan topik praktikum hokum kekekalan massa.

Pelaksanaan praktikum tersebut menggunakan soda kue dan asam cuka sebagai pengganti bahan kimia berbahaya, dalam hal ini dapat memberikan hasil sesuai dengan tujuan praktikum yang ingin dicapai. Adapun tujuan utama dalam pengembangan praktikum berbasis green chemistry ini adalah untuk pencegahan dan pengurangan limbah. Kegiatan percobaan atau eksperimen sangat penting untuk meningkatkan pemahaman konsep siswa terhadap ilmu kimia. Ketersediaan rancangan praktikum kimia berbasis green chemistry, siswa dapat melaksanakan praktikum yang aman bagi kesehatan dan lingkungan tanpa menghasilkan limbah karena tidak menggunakan bahan-bahan berbahaya.

Berdasarkan aspek konstruk, penuntun praktikum berada pada kevalidan yang sangat tinggi. Secara keseluruhan dapat dikatakan bahwa dari aspek konstruk, meliputi kesesuaian format dan keserasian antara gambar dengan materi yang dipraktikumkan sudah valid karena berkaitan satu sama lainnya. Hal ini sesuai dengan pernyataan Van den Akker (1999: 10) menyatakan bahwa, tercapainya validitas konstruk apabila seluruh komponen pada praktikum saling dihubungkan satu sama lain secara konsisten.

Berdasarkan aspek bahasa dan keterbacaan, penuntun praktikum yang dikembangkan berada pada kategori kevalidan yang sangat tinggi. Hal ini berarti penuntun praktikum yang dikembangkan sudah sesuai dengan penulisan kaidah bahasa Indonesia yang baik dan benar, komunikatif dan mudah dipahami. Suatu buku ajar yang baik, termasuk penuntun praktikum harus komunikatif. Komunikatif artinya isi dari buku mudah dicerna, sistematis, jelas dan tidak mengandung kesalahan bahasa (Akbar, 2013:35). Praktikalitas penuntun praktikum berkaitan dengan kemudahan guru dan siswa dalam menggunakannya. Tingkat kepraktisan penuntun praktikum didapatkan dari hasil angket yang diberikan kepada guru dan siswa yang telah menggunakan penuntun praktikum tersebut. Pendapat tersebut sesuai dengan pendapat Nieveen (2007:94) yaitu untuk mengukur kepraktisannya dapat dilakukan dengan melihat apakah guru atau ahli lainnya dapat mempertimbangkan bahwa materi mudah dan dapat digunakan oleh guru dan siswa. Pertimbangan praktikalitas dapat dilihat dari aspek-aspek, seperti: (1) kemudahan penggunaan, terdiri dari: mudah diatur, disimpan dan dapat digunakan dalam jangka waktu tertentu, (2) efisien waktu pelaksanaan sebaiknya singkat, cepat dan tepat (3) perangkat mempunyai daya tarik, dan (4) mudah diinterpretasikan oleh pemgguna baik itu guru ahli maupun guru lain.

Berdasarkan hasil perhitungan angket respon guru pada Tabel 1, didapatkan bahwa penuntun yang 
dikembangkan memiliki kepraktisan yang sangat tinggi yaitu sebesar 0,89 . Interpretasi keseluruhan terhadap praktikalitas yang direspon oleh guru adalah sebagai berikut : (1) penuntun praktikum yang dikembangkan sudah sesuai dengan kurikulum dan alokasi waktu di sekolah, (2) prosedur kerja yang diuraikan dalam penuntun praktikum mudah dilaksanakan, (3) penuntun praktikum ini memudahkan guru dalam melaksanakan praktikum pada materi kimia di semester genap kelas X IPA SMA. Menurut guru penuntun praktikum kimia berbasis green chemistry yang dikembangkan juga memiliki kelebihan dibandingkan penuntun praktikum yang terdapat pada buku siswa dan LKS. Kelebihannya yaitu: pada penuntun praktikum dilengkapi dengan cara pembuatan reagen, menggunakan alat sederhana dan bahan alami, prosedur kerja yang mudah dipahami, tampilan yang menarik dan dilengkapi dengan pertanyaan yang berkaitan lansung dengan kegiatan praktikum.

Berdasarkan hasil perhitungan angket respon siswa pada Tabel 1, didapatkan bahwa penuntun yang dikembangkan memiliki kepraktisan yang sangat tinggi yaitu sebesar 0,81 untuk SMA N I Pantai Cermin dan SMAN I Lembah Gumanti. Interpretasi keseluruhan terhadap praktikalitas yang direspon oleh siswa adalah sebagai berikut: (1) penyajian penuntun praktikum menarik bagi siswa yang sudah pernah praktikum di SMA dan bagi siswa yang belum pernah praktikum di SMA, (2) prosedur kerja pada penuntun praktikum mudah dipahami,3) pelaksanaan praktikum di sekolah membantu siswa dalam memahami konsep dan meningkatkan motivasi belajar siswa. Hal ini berlaku pada siswa yang sudah pernah praktikum dan juga yang belum pernah praktikum di SMA.

Penyajian penuntun praktikum dapat dikatakan menarik berdasarkan respon siswa pada angket praktikalitas. Secara umum, siswa menyukai warna dan gambar yang disajikan pada penuntun praktikum. Penuntun praktikum yang dikembangkan didominasi oleh wana hijau dan orange. Pemilihan warna ini dimaksudkan agar penuntun praktikum mempunyai tampilan cerah. Pemilihan warna penuntun praktikum ini sejalan dengan pendapat Arsyad (2010,91) bahwa salah satu cara yang digunakan untuk menarik perhatian pada media teks adalah warna, huruf dan kotak. Adapun Warna digunakan sebagai alat penuntun dan penarik perhatian pembaca.

Penggunaan gambar membuat penuntun praktikum lebih menarik untuk meningkatkan minat baca, motivasi serta rasa ingin tahu siswa. Sesuai dengan pendapat Sadiman (2012:39) mengatakan bahwa sebuah gambar berbicara lebih banyak dari pada seribu kata. Salah satu kelebihan gambar dapat mengatasi keterbatasan pengamatan, sehingga dengan adanya gambar-gambar dalam penuntun praktikum dapat membantu siswa lebih mudah memahami materi yang 
dipraktikumkan.

Penggunaan berbagai macam huruf dalam penuntun praktikum juga menarik menurut siswa. Penggunaan beberapa jenis huruf untuk menambah kemenarikan penuntun dan menghindari kebosanan siswa saat membaca penuntun, serta dapat membedakan antara materi, judul buku, dan kata-kata penjelas pada gambar ilustrasi. Sejalan dengan pendapat Muslich (2010:308) yang memaparkan bahwa untuk membedakan dan mendapatkan kombinasi tampilan huruf, dapat menggunakan variasi dan seri huruf.

Berdasarkan angket terlihat juga bahwa siswa memahami prosedur kerja pada penuntun praktikum. Untuk penyajian prosedur praktikum diperoleh nilai momen kappa 0,75 dengan kategori tinggi. Selain angket, dapat dibuktikan melalui hasil pengisian komponen tabel pengamatan pada penuntun praktikum oleh siswa. siswa mampu mengisi semua variabel yang diminta dalam tabel pengamatan.

Pelaksanaan praktikum menggunakan penuntun praktikum kimia berbasis green chemistry dapat membantu siswa dalam memahami konsep dan meningkatkan motivasi belajar. Pemahaman konsep siswa dapat dianalisis melalui jawaban-jawaban siswa pada komponen merumuskan hipotesis dan mari diskusi. Secara umum siswa dapat merumuskan hipotesis dan menjawab pertanyaan pada komponen mari diskusi.

\section{SIMPULAN}

Berdasarkan hasil analisis yang diperoleh dari proses validasi dan uji coba, dapat disimpulkan bahwa dihasilkan penuntun praktikum kimia berbasis green chemistry untuk semester genap kelas X IPA SMA. Penuntun praktikum yang dihasilkan telah bisa digunakan untuk mengajarkan materi kelas X IPA SMA karena sudah valid dan praktis, Validitas penuntun praktikum kimia berbasis green chemistry telah dinilai oleh para validator yang menghasilkan kategori sangat tinggi dengan nilai rata-rata momen kappa 0,88 dan praktikalitasnya dinilai oleh 20 orang guru kimia dengan hasil perhitungan nilai momen kappa angket praktikalitas guru 0,89 tergolong kategori sangat tinggi dan diujicobakan pada siswa SMA dengan hasil perhitungan angket respon siswa 0,81 tergolong kategori sangat tinggi.

\section{DAFTAR RUJUKAN}

Akbar, Sa'dun. 2013. Instrumen Perangkat Pembelajaran. Bandung : PT. Remaja Rosda Karya.

Akker, J. Van den. 1999. Design Approachhesand Tools in Education and Training. London: Kluwer Academic Publisher.

Arsyad, Azhar. 2010. Media Pembelajaran. Jakarta: Rajawali Pers.

Chang, Raymond. 2004. Kimia Dasar: Konsep -Konsep Inti Jilid I. Jakarta : Erlangga.

Kapuderwan, Mageswary dkk. 
2011. Greening a Chemistry Teaching Methods Course at the School of Educational Studies, University Sains Malaysia.(online), Descriptive Reports. Vol 5(2): 197-214.

Muslich, M. 2010. Text Book Writing. Jogjakarta: Ar-ruzz Media

Nieveen, N dan Plomp, T. 2007. An Introduction to Educational Design Research. Enschede : Netherlands Institute for Curriculum Development (SLO).

Peratiwi, Ana. 2014. Buku Pedoman

Praktikum Kimia Ramah Lingkungan untuk

Pembelajaran Kimia SMA.

Laporan Penelitian. Tidak diterbitkan. Singaraja : Universitas Pendidikan

Ganesha.

Sadiman, Arif. 2012. Media Pendidikan. Jakarta: Raja Grafindo Persada.

Thiagarajan, Silvasailam dkk. 1974. Instructional Development for Training teachers of Exceptional Children : A Sourcesbook. Indiana: Indiana University. 